\title{
Arnavutluk'ta Ahilik Kültürü ve Toplum Hayatındaki Yeri
}

\author{
FLORIDA KULLA **
}

\begin{abstract}
ÖZ
Bir dinî ve içtimaî teşkilat olarak Ahilik, 13. yüzyılda Anadolu'da görülmeye başlandı. Bir süre sonra Osmanlı Devleti'nin kurulmasında da önemli rol oynadı. Osmanlı'nın fethettiği topraklarda ekonomik, sosyal, siyasî ve dinî yönüyle toplumun yapısında ve gelişmesinde önemli bir unsur oldu. Arnavutça kaynaklarda daha çok "esnaflar" tabiriyle adlandırılan ahiler, kendi içinde bir düzen ve yapıya sahipti. Bu makalede, Arnavut toplumuna değer katan ve zanaatların gelişmesinde önemli rol oynayan Ahiliğin ve ahilerin tarihsel süreçteki konumları mercek altına alınacaktır. Öncelikle 15-18. yüzyıllar arasında Arnavutluk kentlerinin yapısı hakkında, ardından ahilerin "lonca" yönetimi ve içyapısı ile ilgili bilgi verilecektir. Son olarak 19-20. yüzyıllarda esnafların toplumdaki etkisinin azalması ve ortadan kalkmasına değinilecektir.
\end{abstract}

Anahtar sözcükler: Ahilik, Arnavutluk, lonca, esnaflar, zanaatlar

\footnotetext{
A rapçada "kardeşim" ve Türkçede "yiğit", "cömert", "eliaçık" manasındaki Ahilik, 11. yüzyılda İran ve Orta Asya'da, 13. yüzyılda ise Anadolu'da ortaya çıkmıştır. 20. yüzyıla kadar varlı̆̆ını koruyan Ahilik, daha sonra tüm Osmanlı coğrafyasına yayılmış siyasî, sosyal, iktisadî ve dinî-ahlakî bir kurumdur. Etkin olduğu dönemde Ahilik, sanatta mükemmelliği, hizmette olgunluk ve dürüstlüğü, toplumsal hayatta sosyal adaleti ve eşitliği misyon edinen bir kurumdu. Türk toplumu, Anadolu'da ve Rumeli'de bir devlet ve imparatorluk hâline gelmeden evvel, Ahilik nizamı her kentte ve hatta köylerde aynı örf, töre, inanç ve anlayışla insanları ruhen birbirine kenetlemiş,

Bu makale, 17-18 Ekim 2014 tarihinde Üsküp’te düzenlenen "Balkanlarda Türk Kültürü ve Ahilik Sempozyumu"nda sunulmuş bildirinin genişletilmiş hâlidir.

". Doktora öğrencisi, Uludağ Üniversitesi, İlahiyat Fakültesi/BURSA

E-posta: florida_kulla@hotmail.com
} 
büyük birliğe hazırlamıştır (Kazıcı 1988: 540; Ceylan 2014: 11). İlk olarak Abbasi Halifesi en-Nâsir Lidînillah (1180-1225), siyasî ve sosyal durumu gittikçe bozulan ve sarsılan hilâfet otoritesinin yeniden kurulmasında ve içtimâ̂ huzurun sağlanmasında fütüvvet birliklerinin büyük bir güç olacağını fark etmiş ve bu teşekkülleri siyasî otoriteye bağlamıştır. Bununla birlikte Halife, fütüvvetnamelerde bu birliklerin ilke ve kaidelerini düzenleyip diğer Müslüman hükümdarlara da göndererek onları fütüvvet teşkilatına girmeye davet etmişti. Halife bu meyanda Anadolu Selçuklu Devleti'ni teşkilata dahil etmek amacıyla temas kurduğu I. Gıyaseddin Keyhusrev'in nezdine zamanın büyük mutasavvıflarından Şihabeddin-i Sühreverdîyi elçi olarak göndermişti. Aynı dönemde Muhyiddin İbnü'1-Arabi, Evhadüddin-i Kirmani, Şeyh Nasirüddin Mahmûd el-Huyi gibi büyük mutasavviflar Anadolu'ya gelmişti. Bunlardan sonra I. İzeddin Keykâvus ve I. Alaeddin Keykubad'ın da fütüvvet teşkilatına girmesiyle Anadolu'da Ahilik teşkilatı tamamlanmıştı. Bu isimlerden Şeyh Nasiruddin el-Mahmud, sonradan Anadolu'da Ahiliğin kurucusu olarak bilinecek ve Ahi Evran Velî lakabıyla anılacaktır. I. Alaeddin Keykubad'ın desteğiyle İslam düşüncesi ve fütüvvet ilkelerine bağlı kalan Ahilik, tekke ve zaviyelerde şeyh-mürid ilişkilerini, iş yerlerinde usta, kalfa ve çırak münasebetlerini düzenlemiş; Ahi Evran da bu sistemin Anadolu'da kurulup genişlemesinde büyük rol oynamıştır. Debbağlık zanaatı (dericilik) ve tıp bilimi ile uğraşan bir bilim adamı olan Ahi Evran, debbağ esnafının pîri olarak da bilinir (Kazıcı 1988: 540; Tatlılıŏglu 2014: 13). Bu şekilde başlayan Ahilik, zamanla ihtiyaca göre eğitim, idarî, sosyal, kültürel, iktisadî, ticarî, sınaî, askerî ve sosyal güvenlik gibi alanlarda da kendine özgü sistemleri geliştirerek Türk-İslam dünyasında bir medeniyet hareketi olarak değerlendirilebilir.

\section{Osmanlı Öncesinde Arnavutluk'ta Ahilik İzleri}

Balkanlar üzerinde kültürel ve tarihsel açıdan araştırma yapan bilim insanları coğrafî konumu itibariyle bu bölgeyi Doğu ile Batı'nın karşılaşma noktası; kültür, medeniyet ve ideolojik fikirlerin köprüsü olarak nitelendirmişlerdir. Eski İlirya bölgesinin batıda Adriyatik ile İyonya denizi, kuzeyde Doğu Alpler ve Drava, doğuda Danubi-Morava-Vardari ve güneyde de Epir ve diğer Yunan bölgeleri ile sınırlandığı düşünülürse, bu geniş coğrafyanın tarih boyunca birçok medeniyet ve kültürden etkilendiği ve bunların nesilden nesile aktarıldığ1 söylenebilir (İbrahîmi 2003: 198). Ortaçağ'da büyük güçlerin istila etmek istediği Balkanlar, ticarî, askerî, veya dinî sebeplerle erken dönemlerden itibaren uğrak yeri veya ikamet edilen bir bölge olmuştur. Her ne kadar İslam'ın kabulü, çoğunlukla 15-16. yüzyılda görülse bile, kitlesel yayılışının ve Osmanlı yönetiminin kabulünde iki büyük etken vardır: 
a. Bogomilizm Akımı: Orta Çağ Avrupası'nda ortaya çıkmı̧ dinî bir akım olan Bogomilizm, Bogomil adlı bir papaz tarafından başlatılmıştır. Bunlar, Hıristiyan anlayışından farklı olarak teslise inanmıyor, İsa'nın Tanrı'nın oğlu değil, peygamberi olduğunu kabul ediyor, Papalık otoritesini tanımıyor, haç ve ikonlar gibi dinî sembolleri reddediyordu. Özellikle Boşnaklar ve Arnavutlarda, Osmanlı'dan önce etkili olan Bogomilizm, İslam dininin temel esaslarının kabulünde belli ölçüde pay sahibidir (İzeti 2004). Orta Asya'dan Avrupa'ya göç ederek tarihte etkin olan Türk halkarından biri olarak kabul edilen Peçenekler de, Arap-İslam kültürün iyi bir taşıyıcısı olarak nitelenmiştir (İbrahîmi 1999: 209-210).

b. Seyyah Dervişler: Arnavutların İslamiyeti kabul etmesi ile ilgili araştırmalarda, genellikle İslam'ın var olan düzeni bozduğu ve halka kılıç zoruyla kabul ettirildiği var sayılır. Son zamanlarda yapılan çalışmalarda ise tarihsel akış içerisinde Arnavutların İslamiyet'le tanıştıkları ve tedricî olarak kabul ettikleri ileri sürülür. Bu araştırmalarda Sarı Saltık gibi efsaneleşen bir ismin yanısıra, çok sayıda derviş grubunun Balkanlara erken tarihlerden beri geldiklerini ortaya konmuştur. Arnavut asıllı Şemsettin Sami (Sami Frashëri) de Himmetu'l-Hemmam $f i$ Neshri'l-İslam adlı eserinde bu noktaya değinerek tacirler, misyonerler ve göçmenler aracıllğ̆ıyla Osmanlılar gelmeden evvel, bu halkların İslam'la tanıştıklarını belirtir (Frashëri 1994). Ömer Lütfi Barkan'ın da işaret ettiği üzere, Balkanlar'ın bazı bölgelerine gelen bu seyyah dervişler, bir yandan zulüm gören halka İslam esaslarını anlatmış, bir yandan da onlara toplumun inşasında daha hoşgörülü bir anlayışı tanıtmıştır. Bu dervişler birçok bölgede tekke, zaviye ve hangâh açmıştır. Su kaynakları civarındaki tekkelerin yanına değirmenler kurularak bölge halkına ulaşma ve onlarla iletişime geçme amacı güdülmüştür. Yerleşimin olmadığı bölgelerdeki tekkelerse Müslüman muhacirlere iskân yeri işlevini görmüştür. ${ }^{1}$ Ünlü Arnavut roman yazarı İsmail Kadare de bir romanında Sarı Saltık gibi seyyah dervişlerin Via Egnatia üzerinden küçük gruplar halinde geldiklerini işaret ederken, tarihçi ve eski diplomat Ekrem Bey Vlora onları Osmanlı ordusunun öncüsü olarak nitelendirir ${ }^{2}$ (İbrahîmi 2003: 40-41).

Seyyah dervişlerin tekke ve zaviyelerde yürüttüğü faaliyetlerde din, dil ve ırk ayrımı yapmadan halka yakın durması, İslamiyet'in daha hızlı benimsenmesini sağlamıştır. Bu açıdan bakıldığında Raskovec yakınlarında Suku'nun köylerinden Arapaj ve Durres'ta bulunan ayn isimli köy, bu erken tarihlerde bölgeye gelen seyyah dervişlerin etkisini gösterir (Basha 2000: 36-37). Hatta dervişler tarafından kurulan bu tekkeler etrafında daha sonra köyler ve kentler

\footnotetext{
Ayrıca bkz. Barkan 1942; Bakırcı ve Türkan 2013.

2 Daha geniş bilgi için bkz. Ocak 2002; Tuğrul 2014.
} 
kurulmuş; tekkeler, dinî, kültürel ve sanatsal merkezlere dönüşmüştür. Tekkeler etrafinda oluşan yerleşim yerleri de bu tekkeleri ve kurucu derviş gruplarını işaret etmektedir: Şeyhler Mahallesi, Dervişler Köyü, Tekke Mahallesi gibi (Barkan: 1942: 302). Ayrıca 1100 yılında Septe şehrinde dünyaya gelen ünlü Arap gezgin, haritacı ve coğrafyacı Ebu Abdullah Muhammed İdrîsi ile Türk gezginlerinden Evliya Çelebi'nin Arnavutluk dahil dünyanın birçok bölgesini gezip izlenimlerini aktardıkları Nuzhetu'l-Muştak ile Seyahatname adlı eserlerinden de Arnavut kentlerinin 16-17. yüzyıllar öncesi ve sonrasındaki durumları hakkında bilgi edinilebilir (Basha 2000: 42-43). Ancak bu etkenlerden başka İslamiyet'in kabulünde şunlar da etkili olmuştur: 1054'te Doğu ve Batı kilisesinin ayrılmasıyla yaşanan uyumsuzluk, Balkan bölgelerinde dinî ritüellerde devamsızlık, Hıristiyan Bizans ve Sirp din adamlarının halk üzerinde uyguladığı zulüm, zayıf siyasî ve askerî örgütlenme, Slavlarla birlikte gelen Avarlar ve Kumanlar gibi Türk boyları (İzeti 2004: 85-87).

\section{Osmanlı Döneminde Arnavutluk'ta Ahilik}

16. yüzy1lda Arnavutluk'un Osmanlı İmparatorluğu'nun hakimiyeti altında girmesiyle birlikte Arnavutların toplumsal, kültürel ve ruhanî hayatlarında köklü değişiklikler olmaya başladı. Önce tımar sistemi uyguland1, ardından da büyük bir idarî ve askerî birim olarak Sancak-1 Arvanid oluştu. Daha sonra Arnavutluk'un idarî taksimatı değiştirilerek Arnavutluk, İskenderiye, Ohri, Yanya, Berat ve Ergiri sancakları oluşturuldu. Bunlardan ilk ikisi $\mathrm{Ru}-$ meli Eyaleti’ne, diğer üçü de Yanya Eyaleti'ne dahil edildi. Bu idarî sisteme göre kent ve kasabalar Sancak beyinin ve subaşıların hâslarına dahil olup onlara merkez vazifesi görürdü, ki bu dönemde kent ve kasabaların nüfusu çok sınırlıdı. Bunların esas gelirini ziraat mahsulleri teşkil ederdi ve bunlardan sadece "kıst-1 bazar" veya daha sonraki ifadeyle "bâc-1 bazar" denilen vergi alınırd. Köyler ise sipahîlerin oturduğu iskân yerleriydi. Faaliyetleri de tamamen ziraat ve hayvancılığa dayalıydı. Bu köyler arasında bulunmayan kesin sınırlar daha sonra "sınırname" ile belirtilmişti (İnalcık 1987: XII).

Arnavut halkının İslamlaşma sürecinden bahsedilirken genelde iki etken ön plana çıkmaktadır: Birincisi kent nüfusunun İslamlaşması, ikincisi köyden kente İslamlaşmış kişilerin göç etmesi. Var olan zanaatların Osmanlı ordusunun ihtiyaçlarını giderecek şekilde gelişme göstermesiyle ekonomide hareketlenme başladı. Köylerden kentlere göç giderek artmaya başladı. Örneğin 1583 yılında Berat sancağında Fratar, Tozhar, Gjeqar, Dobronik ve Gjerbës gibi civar köylerden gelen 185 Müslüman zanaatkâr kaydedilmiştir. Bu gelen kişilerden bazılarının Abdullah ismini taşıması, İslamiyeti henüz yeni kabul ettiklerini gösterir. Aynı yılda Elbasan kentine de köylerden 36 zanaatkâr göç 
etmiştir $^{3}$ (Duka 1992: 121). Bu değişiklikler büyük yerleşim merkezlerinde oluşan esnaf sistemini de yakından etkiledi. Katolik ve Ortodoks esnafin yan1sıra, özellikle Avlonya ve Dıraç gibi sahil kentlerine yerleşen Yahudi nüfusu da vard1. 15. yüzyılın sonunda İspanya'dan hicret eden 528 Yahudi aileden oluşan büyük bir grup, Avlonya'ya yerleşmişti. Bunlar daha sonra deniz kenarındaki kentlerden iç bölgelere geçmişler ve Evliya Çelebi'nin verdiği bilgiye göre 1670 yılında Berat'ta özel bir mahalle oluşturmuşlardı ${ }^{4}$ (İnalcık 2005: 22-24).

Osmanlı döneminde büyüyen ve gelişen kentler, başlangıçta idarî-askerî merkezler halindeyken, zamanla geleneksel Osmanlı el sanatlarının ve esnafin yerleşmesiyle ticarî-sınaî merkezler hâline gelmişti. Nüfusun artmasıyla kale dışında mahalleler, mezarlıklar, mabedler, bedestenler ve pazarlar oluşmaya başlamıştı. Elbasan ise Osmanlı döneminde kurulmuş olup çok hızlı bir şekilde kentleşme sürecine girmiş, daha sonra civar bölgeler dahil edilerek bir sancak hâlini almıştı. Artık kentlerde hem eski zanaatlar gelişiyor hem de yeni zanaatlar doğuyordu. Ancak en çok ilerleme kaydeden ve halk arasinda yayginlık kazanan zanaat, dericilik oldu, ki neredeyse Arnavutluk'un her kentinde bir "Tabaklar Mahallesi” mevcuttu. Hatta dericilik sektöründen elde edilen ürünler ülke dışına da ihraç ediliyordu (Shkodra 1963: 3-6). Her renkte ve çeşitte derinin işlenmesiyle ünlenen kentler, zamanla daha çok tüccar çekmeye başladı. Bunun yanısıra saraçlık, kürkçülük, madencilik, kuyumculuk ve dokumacılık da gelişen zanaatlar arasındaydı. Cami, köprü, yol, çeşme ve kaldırım yapımında da Arnavutların özel bir ustalığı vardı. Yemek konusunda ise Elbasan firınciları ile Arnavut biberi ün kazanmı̧̧ı. Sadece Elbasan kentinde 17. yüzyılın ilk yarısında 45 zanaat bulunmaktayd. Bunlardan bazıları şunlardı: takkeciler, dericiler, pabuççular, ipek üreticileri, terziler, berberler, nalbantlar, bıçakçılar, kuyumcular, kürkçüler, demirciler, firıncılar, eyerciler, okçular, kasaplar, simitçiler, kahveciler, kılıççılar, kıyafet üreticileri, kazancılar, saz yapım ustaları, duvar ustaları, mum üreticileri vb. Bu gibi zanaatlar Berat, Prizren, İşkodra, Üsküp ve Akçahisar'da da yaygınd $1 .{ }^{5}$

Bu gelişmelerle birlikte kent ekonomisi, özellikle de zanaatlar ve mal ticareti esnaf loncalarının idaresi altına girmişti. Kent ekonomisinin ilerlemesinden sorumlu olan esnaf, aynı zamanda mabetlerin bakımında ve finansmanında önemli bir rol oynadı. Toplumla işbirliği hâlinde mabetlerin idaresi esnaf loncalarına geçti. Kentsel yaşamın gelişmesi ve dinî kurumların artmasıyla esnafın işlev ve görevleri arttı. Bunların yürütülmesi için teşkilatların yöneticileri özel komisyonlar oluşturdu. Bu komisyonlar cami, tekke ve mescitlerin

\footnotetext{
Bkz. Cebeci ve Kırpık 2006.

4 Bkz. Shpuza 1993; Pulaha 1988.

5 Bkz. Shkodra 1973; Dollma 2012; Frashëri 2008.
} 
ihtiyaçları ile yakından ilgileniyordu. Vakıfların ve zengin Müslümanların yaptığ 1 yardımlarla cami ve mescitlerin inşası gerçekleştiriliyor, gerekli ihtiyaçları karşılanıyordu. Elbasan'dan debbağ esnafi, bu teşkilatın katkılarıyla inşa edilen Elbasan camii ve tekkesinin bakımını üstlenmekle birlikte, küçük bir yerleşim biriminde bulunan Peqin Pazarı Camii'nin de masraflarını karş1lyyordu (Shkodra 1992: 139). Evliya Çelebi, Seyahatname'sinde Berat'ta Varosh merkezinde bulunan ve esnafın adını alan Paşmakçılar mescidinden bahsediyor. ${ }^{6}$ Tekkelerin büyük bir kısmı da esnaftan maddî ve manevî destek görüyordu. Bu sayede sayıları sürekli artan dinî kurumlar yayılıyor, halka daha fazla hizmet veriyordu.

Örgütlenmiş bu teşkilatların dinî kurumlarla ilişkisi dinî yönden de güçlüydü. Zira bu loncalar şeyhleri ve peygamberleri birer pîr kabul ediyorlardi. Örneğin, Hz. İdris kürkçülerin ve terzilerin pîri olarak bilinirken, Hz. Şit yelkenlerin yapımında ve yünün işlenmesinde pîr sayılıyordu. Buna göre, s1rasıyla Hz. Nuh marangoz ve denizcilerin, Hz. Zülkifl firınciların, Hz. Lokman berber ve cerrahların, Hz. Davud kılıç, mızrak, ok ile zırh üreticilerinin, Ahi Evran Velî de debbağ esnafının pîri sayılıyordu. Çiftçi olan Hz. Adem'in oğulları ve onlardan sonra gelenler onlarca zanaatı icad edip yaydılar. Bu pîrlerin anısına yılda bir gün kutlama yapılırdı. Müslüman zanaatkârlar 12 ayrı derviş koluna mensup oldukları için, kutlamaları da mensup oldukları bu kollara göre yaparlardı. Bu esnaf bayramlarını daha iyi değerlendirebilmek için tekke ve manastırların yanında ticarî esnaf fuarları düzenlenirdi. Esnaf, kendi cemaatine ekmek, zeytin ve peynir dağıtırdı. Ritüllere katılanlar, asayiş̧i sağlamak için görevlendirilmiş, kentin dişından gelenler için para toplardı. Mesela Büyük Debre fuarında 19. yüzyıla kadar bu görevi Elbasanlılar yürütürdü. Hıristiyan esnaftan farklı olarak, Müslüman esnaf kendi pîrlerinin günlerini tekke ve zaviyede kutlard1. Esnaf tekkede zikir yapar ve geleneksel helvadan yerdi. Dericiler, saraçlar ve kunduracılar Ramazan ayının son gecesini kutlar ve yardım toplarlardı. Genel olarak ise esnaf Ramazan Bayramını, Kurban Bayramını, Mevlid kandilini, Nevruz'u, Hıdrellez'i ve Aşure gününü kutlardı. Hacca gitmek ve hacca gidenleri uğurlamak da ayrı bir gelenek hâline gelmişti. Hidrellez (Shëngjergii) ise hem Müslüman hem Hıristiyanlar tarafından kutlanırdı. Özellikle İşkodra’da ya Baba Kamberi Türbesi'nin yanında ya Drisht köyünde ya da Rozafa kalesinde kutlanırdı. Camiiler ve namazgâhlarda esnaflar önemlerine göre saf tutardı. Ancak Müslümanların dinî kurumlarla bağlantıları 17. yüzyılda daha güçlüydü. Bunu Elbasan'ın bu yüzyıldaki fütüvvetnâmelerde veya dericilerin pîrnamelerinde görülebilir. $\mathrm{Za}$ man içerisinde esnaf, daha rahat edebildikleri Ahi-Kadirîlik ve Bektaşîliği

Berat hakkında verdiği bilgilere göre, 1670 yılında şehirde toplam 30 camii ve mescid ile 5 medrese bulunmaktadır (Aktaran Basha 2000: 56-58). 
seçmeye başladı. Evliya Çelebi'nin eserinden, camii ile mescitlerin yanı sıra kentlerde çok sayıda tekkenin de bulunduğu ve bu konuda öne çıkan kentlerin Gjakova, Tetova, Kruja (Akçahisar) ve Ergirikasri olduğu öğrenilmektedir. Arnavutluk bölgesinde en yaygın olan tarikatlar ise Kadirîler, Bektaşîler, Halvetîler, Rifaîler ve Mevlevîler idi.

Bu tarikatlar kardeşlik, üyeler arasında eşitlik, sabır, tevazu ve alçakgönüllülük gibi hasletleri telkin ettiklerinden, zanaatkârlar arasında geniş bir kabul gördüler. Ancak bunlar arasında en önemlileri Ahi-Kadirîlik ve Bektaşîlik'tir. Bunlar Gjakova, Prizren, Tetova ve Akçahisar'da yaygınlık kazanmıştır. Bektaşîler, daha çok silah imalatçıları ve çilingirleri yanlarına çekerken, AhiKadiriler Tiran, Elbasan, Berat, Pejë ve Priştine'de yaygın olup dericiler, saraçlar ve pabuççular üzerinde etkiliydi. Arnavut ahileri arasında da diplomanın (icazetnâme) verilmesi, kalfa ile çıraklara "şed kuşatılması" gibi ritüeller tamamen Ahi Evran tarafindan düzenlenen Fütüvvetnâmèye dayanıordu. $\mathrm{Bu}$ eserde peygamberlerden ve özellikle Hz. Muhammed'in ashabından, ardından da pîrlerden ve onların arkadaşlarından söz edilmektedir. 17 nesilden oluşan pîr ve arkadaşlarından söz edilirken bunların her birinin Hz. Ali şeddini kuşandığ 1 da belirtilmektedir. Ancak zanaatkârlar 16. yüzyılda gelişmiş esnaf seviyesine henüz ulaşmış değildi. Bu süreç ancak 17. yüzyılda başarı ile tamamland1. Arnavut kentlerinin büyük kısmında zanaatkârlar örgütlendi ve bu noktada esnaf grubunu düzenleyecek bir sisteme ihtiyaç duyuldu. Ahilik, zanaatkâr ruhuna en yakın sistem olarak geniş destek buldu. Dönemin geçerli kanunları ile de uyum sağlayan bu sistem, devlet tarafindan desteklendi ve kanun olarak onayland. Sultan III. Mustafa'nın fermanına göre Osmanlı İmparatorluğu'ndaki her esnaf, Ahilik sistemine riayet etmeliydi. Bu şekilde kanunnameler, kadı sicilleri ve fütüvvetnameler o dönemden bu yana oluşan tüm hükümler, kural ve kanunların ana omurgasını oluşturmuştur.

\subsection{Pazar Fizyonomisi ve Ticaret}

Zanaatların artması ve gelişmesiyle bölgesel pazarlarda dükkânların sayısı arttı. Öyle ki 17. yüzyılda Elbasan pazarında 900 dükkân hizmet veriyordu. İşkodra, Prizren ve Berat'ta yaklaşık bu sayıda dükkân bulunuyordu. ${ }^{7}$ En çok dükkân ise 2150 adet ile Üsküp'te bulunuyordu. Bu da Balkan genelinde en büyük pazarlardan birinin Arnavut pazarı olduğunu gösterir. Gjirokastra, Gjakova, Prishtina ve Kavaja gibi daha küçük yerleşim birimlerinin pazarlarında 200-300 arası dükkân hizmet veriyordu. Pazarlar genel itibariyle yaşam alanların dışında tek bir yerde toplanıyor, dükkânlar da zanaata göre sırala- 
nıyordu. Böylece tüccarlar, Prizren'de 24, Elbasan'da 30 sokağı kapsıyordu. Bu sokaklardan her birinde ayrı bir zanaatin ürünleri sergileniyordu. Dar sokaklardan oluşan ve birkaç dükkânın birbiriyle birleştiği pazarlar "çarşı" adını alıyordu. Genel itibariyle bu dükkânlar, han ve hamamlarla birlikte vakıfların idaresi altındaydı. Ancak bu dükkânların hepsi zanaatkârların mülkiyeti altında değildi, bazıları kiralanmıştı.

Kayıtlara göre, Elbasan'da terziler sokağında bir dükkânın kirası aylık 15 akça, dericiler sokağında ise yıllık 400 akçayd.. Genel itibariyle kira günlük 1-1.5 akça arasında değişiyordu. Dükkân sahipleri ayrıca aylık 1 akçayı gece bekçileri için, "battal kirası" adını alan küçük bir miktarı da mahalle camileri için veriyordu. Yani kentteki her caminin bakımı ve ihtiyaçları belli bir zanaat sokağından toplanan battal kira miktarı ile karşılanıyordu. İç ticaretin artı̧̧ göstermesi ile daha kolay muhafaza edilmesi ve muhtemel yanginlardan ko-

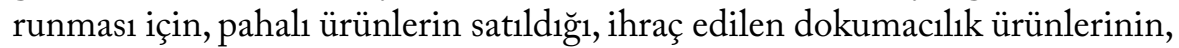
kuyumcu dükkânlarının yer aldığı ve daha çok bölgenin zengin kesimine hitap eden kapalı çarşılar, yani genelde taştan yapılmış bedestenler inşa edildi. İlk bedesten örnekleri Prizren, Üsküp, Manastır ve Elbasan'da görülür. Daha sonra bunlar Kavaja, Berat, İşkodra ve Janina'da inşa edildi. Bu bedestenlerin genelde bir veya birden fazla demir yahut ahşap kapıları olurdu ve geceleyin bekçiler tarafindan korunurdu. Bedestenlerin açılmasıyla birlikte dövizcilik de gelişmeye başlamıştı. Ayrıca her kentte genelde haftada bir açılan ve zırâ̂ ürünlerin, arada el işlerinin de satıldığı mahalle pazarları vardı, ki bunlar daha çok mabedlerin etrafında kurulurdu. Dükkân ve bedestenler gibi esnaf loncalarının yönetiminde olan bu pazarlar, Pazar günleri kurulurdu ve bu gelenek 19. yüzyılın ortalarına kadar devam etti. Ayrıca ekonominin zenginleşmesine yönelik, yılın belirli günlerinde düzenlenen fuarlar aç1lırdı. Bunlar genellikle dinî bayramlarda yapılır ve elde edilen kazanç yerli halka ulaştırılırdı. En çok fuarın düzenlendiği ve ticaretin aktif olduğu Elbasan'dan sonra, bu fuarlar Struga gibi diğer kentlerde de düzenlenmeye başladı. Bu ekonomik hareketlenmeler hem Anavut bölgelerinin birbirine daha çok yakınlaşmasına hem de diğer Balkan ülkeleri, Dalmaçya ve Venedik ile daha düzenli ticaret ilişkilerinin kurulmasina vesile oldu.

İhracat ürünleri genellikle yün, deri, yağ, mısır çeşitleri, et ve katrandı. İthalat ve ihracatın gelişmesiyle Arnavut limanlarının değeri arttı. Böylece İşkodra ve Avlonya limanlarının yanısıra, Dıraç (Durres) limanı da değer kazandı. 17. yüzyılın sonuna gelindiğinde bu limanda Ulqin, Fransa, Hollanda, Raguza, Venedik ve İngiltere'nin ticaret gemileri bulunuyordu. ${ }^{8}$ Önce büyük kentlerde taifeler şeklinde örgütlenen ve daha sonra bu geniş̧ çapta gelişmiş

$8 \quad$ Bkz. Shkodra 1992. 
ekonomiyi yakından takip eden ve yöneten esnaf loncaları, kendi hiyerarşik sistemlerini belirginleştirdi. Doğruluk, emniyet, cömertlik, tevazu, arkadaşlarına nasihat etme, onları doğru yola sevketme, affedici olma, bencil olmama ve uyanıklık gibi özelliklere sahip olan Ahilik esnafi, toplumun sadece ekonomik yönden değil, sosyal, siyasî, eğitim ve hatta askerî yönden de gelişmesine katkıda bulundu.

Genel itibariyle bakıldığında Arnavutluk'un Müslüman nüfusu ve esnafi, kalelerin muhafazası, isyanların bastırılması ve vergilerin toplanmasından sorumluydu. Hıristiyan nüfus ise kalelerin, köprülerin, yolların bakımından sorumluydu. Esnafın başını çektiği bu faaliyetlerde bazen zanaatkâr gruplar arasında anlaşmazlık çıkıyordu. 1580 yılında Elbasan kadısına ulaşan bir şikâyetten, dericiler, çulhacılar ile pabuç üreticileri arasında anlaşmazlık çıktığı anlaşılıyor. 16. yüzyılın sonunda Berat, Elbasan, İşkodra, Prizren, Peja ile Vulçiterm kentlerinin genelinde 1686 Müslüman, 39 Hıristiyan zanaatkâr vardı. Tüccar ise iki gruptan oluşuyordu: gıdaları ve zırâi ürünleri satan bakkallar, kentler ile ülkeler arası ticaret yapan tâcirler. ${ }^{9}$

\subsection{Arnavut Esnafinın İç Yapısı}

a. Çırak: Esnaf olmanın yolu, Ahilik öğretisine göre çıraklıkla başlar, kalfalıkla devam eder ve ustalıkla nihayetlenir. Bir kişi ancak "usta" olduğunda esnaf üyesi olabiliyordu. Zanaatın geliştiği ve muhafaza edildiği bu hiyerarşik yapıda, bir ustanın dükkânında yıllarca zanaatin inceliklerini ve Ahilik’i öğrenmeye çalışan çırağın konumu, 1773 yılında Sultan III. Mustafa tarafından verilen, Ahi Evran Veli öğretilerinin bir nevi özeti olan fermandan öğrenilmektedir. Buna göre çırak, ustasından öğrenmeli, ona sayg1 göstermeli, sözünü dinlemeli ve ağırbaşlı olmalıydı. Bunları yapmadan ustalığa yükselemez, hatta kendi dükkânını da açamazdı.

Usta, çırağı lonca büyüklerinin onayı ile kabul eder, sonra da mesleğini öğretirdi. "Eti senin, kemiği benim" ifadesi, çırağın ailesince ustaya bu sırada söylenirdi. Şayet usta, kâhyanın onayı olmadan dükkânına bir çırak alırsa, kendisine ceza verilirdi. Bu, Elbasan'daki kürkçüler kanunnamesinde açıkça yazılıydı. Onay alındıktan sonra usta, çırağın ismini esnaf defterine kaydederdi. Şayet çırağın babası tanınan ve esnaf loncasına üye olan bir zanaatkâr ise, o zaman babasının adı da yazılırdı. Ayrıca Arnavutluk'ta çırakların kabul edildiği ve kaydediliği tarihler belliydi. Şöyle ki, Elbasan ve İşkodra'da çıraklar, Shen Gjergji (Hıdrellez) kutlamasında kabul edilirdi. Berat ve Korça'da ise "Struga Günü" olarak bilinen 8 Eylül'de kabul edilirdi. 17. yüzyıldan iti-

9 Bkz. Thengjilli 2005. 
baren çırak kayıtları, örneğin Elbasan kürkçülerinde 5000 aspra ve 5 kuruş vermekle yapılıyordu. Bazen çırağın bir ustanın oğlu olması şartı aranırdı. $\mathrm{Bu}$, bazı zanaatların bir ailenin tekelinde kalmasına yol açıyordu. Bu duruma daha çok kuyumculuk, kürkçülük ve terzilik alanında rastlanıyordu. Ayrıca Üsküp, Peja, Prizren, İşkodra, Elbasan ve Berat kentlerinde deri, saraciye, takke, paşmak, çilingir ustaları ve berberler, kendileriyle aynı dine mensup olan çırakları almaya özen gösterirlerdi. Bunlardan başka çırakların kabulünde ahlakı, ailesinin konumu, fizik yapısı gibi etkenler de gözetilirdi. Çırağın dürüstlüğünü sınamak için dükkân köşelerine para bırakılır ve çırağın onları haber verip vermemesine dikkat edilirdi.

Ustanın çırak üzerinde fiziksel şiddet uygulaması, lonca kanunnamelerine göre ağır ceza gerektirirdi. Ne var ki, her ne kadar fütüvvetnameler ve fermanlar çırak-usta ilişkisini düzenlese de, pratikte aralarındaki ilişki her zaman kurallara göre olmazdı. Özellikle piyasada talep artışıyla birlikte bazı ustalar, çıraklarına düşük maaş vererek onların hakkını istismar etmekteydiler. Çocuğu olmayan ustaların yetim veya fakir çırakları evlat edinme vak'aları hariç, her zaman kurallara uygun ilişkiler söz konusu değildi. ${ }^{10}$ Çırağın ağır suç işlediği durumlarda falakaya yatırılır, usta ile ebeveyn arasında düzenlenen sözleşme süresi bitmeden çırak ustadan ayrılamazdı.

b. Kalfa: Uzun müddet ustanın yanında kalıp mesleğin püf noktalarını öğrenen ve bunun yanısıra ahlakî ve dinî öğreniminde belli bir noktaya gelen çırak, ustanın esnaf yöneticilerine yönelttiği teklif ile kalfalığa yükselirdi. Genellikle kalfalığa kabul, dinî ritüellerle kutlanır ve yeni kalfa esnaf defterine kaydolunurdu. Bunun karşılı̆̆ında 450-500 akça kadar vergi verirdi. Kalfalık süresi 4-5 yıl kadar devam ederdi. Ayrıca ustalığa geçiş için her zanaatın kendine göre belirlediği bir yaş sınırı vardı; bu 22-30 arasıydı. Örneğin, Raguza kunduracıları 23 yaş altında kimseye ustalık payesini vermezlerdi. Kalfanın işlediği suçlar için şeyh veya esnaf büyükleri tarafından farklı cezalar verilirdi. Kalfalık sürecindeki kişi hem öğrencilik hem iş yapardı. Kanunnamelere göre, kalfaların ücretleri ilk yıllarda günlük, daha sonra haftalık şeklinde ödenirdi. Ücret miktarı ise lonca yönetimi tarafindan belirlenirdi.

Farklı zanaatlarda çalışan bekâr kalfalar, bekâr taifelerini veya teşkilatlarını oluştururdu. Arnavutluk'un farklı bölgelerindeki bu uygulama, Berat'ta 1823 yılında inşa edilen Bekârlar Camii'nde görülebilir. Bu bekâr birliklerine ancak belli bir yaş grubu ve zanaata mensup olan bekârlar kabul edilirdi. Evlenenler ise üyelikten çıkarılırdı. Kendi kanunnameleri bazında işleyen bu yapıların en önemli özelliği, üyeler arasında yardımlaşmak ve birbirini korumaktı. Üyele-

\footnotetext{
10 Geniş bilgi için bkz. Shkodra 1962 ve 1992.
} 
rin başında en az bir imam ve bayraktar kadar önemli olan "bekârbaş̧" bulunurdu. Ayrıca bekârların beraber kaldığı "bekârhane"leri veya "bekâr odaları" vardı. Bunun en bilineni Elbasan'daki Tabaklar Köşkü’dür. Bekârların sayıları ve oluşturdukları birlikler gittikçe artmıştır.

Bir kalfanın hayatında en önemli olay, bağımsız bir usta olarak ilan edilmesiydi. Kalfa, belirlenen süre tamamlanınca ustasına teklif yöneltir, o da loncaya sunard1. Kabulü üzerine "icazet verme" veya "teferrüç" töreni için gerekli hazırlıklar yapılırd. Törene gelenler önce eğlenir, daha sonra "şedd kuşanma” gerçekleşirdi. Esnaf loncası, bu ritüeli düzenlemek için önce kadıdan, ardından da yeniçeri ağasından izin ister ve bu ritüele bölgenin önde gelen şahsiyetlerini davet ederdi. Gelen davetliler ise çeşitli hediyeler getirirdi. Bunlar ustabaşı tarafından kayda alınır ve halka dağıtılırdı. Bu ritüeller bazen günlerce sürer ve gelen davetliler için çok özel yemekler hazırlanırdı. İcazet töreninin düzenleneceği meydanda bir tarafta kalfa ve çıraklar sıralanır, diğer tarafta "esnaf kurulu" yer alırdı. Kurulun başında ise şeyh bulunurdu. Dervişlerden biri veya esnaf çavuşu yanına usta adayını alır ve ahi babayı selamlard. Kanunnamelerde belirlenen karşılıklı konuşmadan sonra çavuş, kalfa için icazet isterdi. İcazet verildiği takdirde usta kalfaya şeddini kuşatır, yeni usta da hem kendi ustasının hem de şeyhin elini öper, onlardan dua alır ve ardından kendisine bir nevi yazılı diploma olan tasdikname verilirdi. Ancak bu ritüelden sonra yeni usta vergisini ödeyebilir ve dükkânını açabilirdi. Lonca yönetimi yeni dükkân açıldıktan sonra kontrolü sürdürür, bir yolsuzluğu veya kusuru tespit ederse dükkânı kapatırdı.

c. Usta: Dükkânın açılması ustanın kendi imkânları veya eski ustanın yardımlarıyla olur ve ardından küçük bir kutlama yapılırdı. Esnafa üye olan kimseler birbirlerine "yoldaş" diye hitap ederlerdi. Fütüvvetname-i Kebire göre ustalar kendi aralarında üç gruba ayrılırdı: kavlî, şurbî ve seyfî. Yeni ustalar ayrıca şer'i mahkemelere kaydolurdu. Ancak ustaların zenginleşmesi ve güç kazanmasıly aralarındaki rekabet gitgide artard. Ustalar belli toplantılara katılır ve şedd merasimlerine giderdi. Ayrıca esnaf, yıllık üyelik vergisini öderdi. Ustaların suç işlediği durumlarda kendilerine ceza uygulanırd. ${ }^{11} \mathrm{Bu}$ ustaların geliri her zaman iyi olmazdı. Bir kısmının maddi durumu iyiyken, çoğunluğu yillarca teşkilata borçlu olurdu.

ç. Lonca: Lonca heyeti esnaflar için idarî yargı konseyinin rolünü oynuyordu. Heyet, 17. yüzyılın başından beri mevcuttu. Bu heyet ihtiyarlar ve ağalardan, yani eski esnaftan oluşurdu. Üyelerin sayısı 3-5 arasında değişmekteydi. Bu heyetin başında şeyh yani ahi baba, sonra esnaf başı, yiğitbaşı ve onun yar-

$11 \quad$ Bkz. Zamputi 1961. 
dımcısı gelirdi. Elbasan dericilerinin lonca heyetinde fakı, bayraktar ve yiğitbaşı da bulunurdu. Daha sonra buna ustabaşı, mütevelli, çavuş, kalfabaşı ve bekârbaşı da eklenmişti. Bu kadar kişiden oluşan lonca, genelde büyük esnaf gruplarının loncasıydı. Sultan III. Mustafa'nın fermanında belirtildiği üzere, lonca heyeti üyeleri oylamayla seçilir ve heyet sultanı bir nevi temsil ederdi. Yerel yönetimden kimse onlara müdahale edemez, saygisızlık yapamazdı. Durum böyle olunca kararları tartış1lmazdı. Lonca heyeti, ustaların atanması; ustabaşı, çavuş, mütevellinin seçilmesi; fiyatların, harcamaların, kalfa ücretinin belirlenmesi ve savaşa dair kararların alınmasında etkindi.

d. Ahi Baba: Fermana göre şeyh yani ahi baba, daima esnafin ruhanî lideriydi. Hiristiyan esnaflarda bu görevi papaz veya kâhya yürütürdü. Kayıtlardaki ilk ahi baba bilgisi, 1580 yılında Sefer Kalfa adında bir ahi babanın kadıya başvurmasıdır. Aynı mahkemeye 26 yıl sonra Hasan Belshi adında bir ahi baba başvuruda bulunur. Ahi babalar aynı zamanda ülkede Kadirî tekkelerinin temsilcisidir. Kırkent dervişleriyle bağları olan bu kişiler aynı zamanda Sultan'ın otoritesini sağlar. Ancak en fazla ahi baba ismine, Ahi Evran Velînnin pîri olduğu derici esnafında rastlanır. Hatta her yıl Kırkent’teki Ahi Evran tekkesine belirli miktarda para gönderilirdi. Özel kararlarla donatılan Kurkent halifeleri, dericilerin tekke, zaviye ve camilerini ziyaret edip Ahilik ilkelerini öğretirdi. Bu seyyah halifeler, gittikleri bölgelerde ahi babalara görev dağıtır, onlar da bu görevi eksiksiz yerine getirirdi. Ahi babalar şeriatı, tarikati, hakikati ve marifeti öğretirdi. Aynı zamanda çok iyi zanaatkâr olan bu kişiler, zekaları ile de tanınırdı. Ahi baba kalfalara ve çıraklara hırka giydirip şed kuşatırdı. Yeni ahîlere, kâhyalara, yiğitbaşlara ve bayraktarlara taç takardı. Ayrıca esnaf arasındaki anlaşmazlıklarda hakemlik ederdi. ${ }^{12}$

\section{Sonuç}

Osmanlı hakimiyeti ile birlikte özellikle kent yapısında olumlu etkisi bulunan Ahilik öğretisi, Arnavutluk toplumunda derin izler bırakmıştır. Önce tekke ve zaviyeler inşa eden, ardından esnaf teşkilatlanması ve örgütlenmesi sonucu toplumu her yönüyle inşa eden Ahilik, Kırkent'ten hatta ondan öncesinde Bağdat'tan Arnavutluk diyarına uzanan tarihsel bir gerçekliktir. Ahilik, 19. yüzyılın sonu ile 20. yüzyılının başında Osmanlı İmparatorluğu'nun gücünü yitirmesiyle etkisini kaybetmiştir. Günümüzde Ahilik'in etkin olduğu dönemde gelişen zanaatların çok azı hayatta kalabilmiştir.

\footnotetext{
12 Bkz. Shkodra 1973.
} 


\section{Kaynaklar}

Bakırcı, Nedim ve Hüseyin Kürşat Türkan (2013). "Tekke ve Zaviyelerin Balkanlar'daki Rolü ve Önemi”, Türk Dil, Edebiyat ve Halkbilimi Araştırmaları Dergisi 1, s.145-160.

Barkan, Ömer Lütfi (1942). "İstila Devirlerinin Kolonizatör Türk Dervişleri ve Zaviyeler”, Vakıflar Dergisi 2, s.279-304.

Basha, Ali M. (2000). Islami në Shqipëri gjatë Shekujve, Tiran: y.y. [Yüzy1llar Boyunca Arnavutluk'ta İslam]

Cebeci, Ahmet ve Güray Kırpık (2006). "Tahrir Defterlerine Göre Osmanlı Fethinden Sonra Arnavutluk'ta Hiristiyan ve Müslüman Nüfus Değişmeleri”, Balkanlarda İslam Medeniyeti, İstanbul: IRCICA Yayınları, s.290-297.

Ceylan, Kazım (2014). “Türk-İslam Medeniyetinin Öncülerinden Ahî Evran Velî ve Medeniyetimize Etkileri”, Türk Dünyası Bilgeler Zirvesi-Gönül Sultanları Buluşması.

Dollma, Baki (2012). Zejtaritë Tradicionale të Krujës dhe Kurbinit, Tiran: Marlin Barleti. [Akçahîsar ve Kurbin Bölgesinin Geleneksel Zanaatları]

Duka, Ferit (1992). "Momente të Kalimit në Islam të Popullsisë Shqiptare në shek. XV-XVII", Feja, Kultura dhe Tradita Islame ndër Shqiptarët, Priştine: y.y., s.119-126. [XV-XVII.yy'da Arnavut Nüfusunun İslam’a Geçiş Örnekleri]

Frashëri, Kristo (2008). Historia e Qytetërimit Shqiptar-Nga Kobët e Lashta deri në Fund të Luftës së Dytë Botërore, Tiran: Akademia e Shkencave e Shqipërisë. [Arnavut Medeniyetinin Tarihçesi- Antik Dönemden II. Dünya Savaşı'na Kadar]

Frashëri, Sami (1994). Përhapja e Islamit, Üsküp: Logos-A. [İslam'ın Yayılmas1]

İbrahîmi, Nexhat (2003). Islami dhe Muslimanët në Tokat Shqiptare dhe në Ballkanin Mesjetar-shek. IX-XIV, Üsküp: Logos-A. [Arnavut Topraklarında ve Ortaçağ'da Balkanlarda İslam ve Müslümanlar, IX-XIV. Yüzy1llar]

__ (1999). İslami në Trojet İliro Shqiptare Gjatë Shekujve, Üsküp: Logos-A. [Asırlar Boyunca İliryalı Arnavut Topraklarında İslam]

İnalcık, Halil (1987). Hicri 835 Taribli Sûret-i Defter-i Sancak-i Arvanid, Ankara: Türk Tarih Kurumu Basımevi. (2005). “Türkler ve Balkanlar”, BAL-TAM Türklük Bilgisi 3, s.20-44.

İzeti, Metin (2005). "Arnavutlar ve Bektaşilik", Uluslararası Bektaşilik ve Alevilik Sempozyumu I, Isparta: y.y., s.517-525.

- (2004). Kllapia e Tesavoufit, Shkup: Fakulteti i Shkencave İslame. (2001). Tarikati Bektashian, Tetovë: y.y. [Bektaşi Tarikat1]

Kazıc1, Ziya (1988). "Ahilik", Diyanet Íslam Ansiklopedisi, İstanbul: TDV Yayınevi, s.540-542.

Kodra Hysa, Armanda (2002). "Pazaret e Vjetra të Qyteteve Shqiptare në Fund të Shek. XIX. dhe Fillim të Shek”, Yayımlanmamış doktora tezi, Tiran: Tiran Üniversitesi. [19. Yüzyılda Arnavutluk Kentlerinin Eski Çarşıları]

Ocak, Ahmet Yaşar (2002). Sarı Saltık: Popüler İslam’n Balkanlar'daki Destanî Öncüsü, Ankara: Türk Tarih Kurumu Yayınları. 
Pulaha, Selami (1988). Pronësia Feudale në Tokat Shqiptare (Shek. XV-XVI). Tiran: Akademia e Shkencave e RPS të Shqipërisë. [Arnavut Topraklarında Feodal Mülkiyet, XV-XVI. Yüzyıllar]

Shkodra, Zija (1962). "Problemi i Çirakut në Sistemin e Esnafeve Shqiptare”, Buletin i Shkencave Shoqërore 2, s.35-45. [Arnavut Esnafları Sisteminde Çırakların Sorunu]

— (1963). "Rreth Tregtisë së Sanxhakut të Shkodrës me Republikën e Venedikut gjatë shekullit të XVIII”, Sosyal Bilimler Bülteni 1, s.3-21. [XVIII. Yüzyılda İşkodra Sancağ 1 ile Venedik Arasındaki Ticaret Üzerine]

(1973). Esnafet Shqiptare (Shek. XV-XX), Tiran: Akademia e Shkencave e RPS të Shqipërisë. [Arnavutluk Esnafları, XV-XX. Yüzyıllar]

(1992). "Islam’i dhe Institucioni Esnafor në Shqipërinë Etnike”, Feja, Kultura dhe Tradita Islame ndër Shqiptarët, Priştine: y.y., s.139-145. [Etnik Arnavutluk'ta İslam ve Esnaf Teşkilat1]

Shpuza, Gazmend (1993). “Arnavutluk'ta Yahudiler”, Osmanlı Araştırmaları 13, s.3943.

Tatlılıŏlu, Kasım (2014). "Ekonomik Sorunlarına Genel Bir Bakış Açısı”, Türk Dünyası Bilgeler Zirvesi-Gönül Sultanları Buluşması, Eskişehir: y.y.

Thengjilli, Petrika (2005). "Faktorët për Përhapjen e Fesë Islame në Shqipëri (shek. XVI-XVIII)”, Perla 2 (37), s.54-72. [XVI-XVIII. Yüzyıllarda Arnavutluk'ta İslam'ın Yayılmasındaki Etkenler]

Tuğrul, Talip (2014). "Sarı Saltık’ın Tarihî ve Menkıbevî Hayatı", Türk Dünyası Bilgeler Zirvesi - Gönül Sultanları Buluşması,Eskişehir: y.y.

Zamputi, İnjac ve Stavri Naçi, Zija Shkodra (1961). Burime të Zgjedhura për Historinë e Shqipërisë, Shqipëria nën Sundimin Feudal - Ushtarak Otoman (1506-1839), Tiran: Universiteti Shtetëror i Tiranës. [Arnavutluk Tarihi için Seçme Kaynaklar, Osmanlı'nın Feodal-Askerî İşgali Altında Arnavutluk (1506-1839)] 


\begin{abstract}
Akhism Culture in Albania and Its Place in Social Life

Akhism, as a religious and social organization, began to appear in Anatolia in $13^{\text {th }}$ century. After a while, it played an important role in the establishment of the Ottoman Empire. It also became an important element in the structure and development of the society from economic, social, political, and religious aspects in the land conquered by the Ottomans. Generally called "craftsmen" in Albanian sources, akhis had an order and structure in itself. In this article, the position of Akhism and akhis, which play an important role in the development of crafts and add value to the Albanian community will be examined. Firstly, the structure of Albanian cities between $15^{\text {th }}$ and $18^{\text {th }}$ centuries will be portrayed. Secondly, "guild" management and internal structure of akhis will be discussed. Finally, reduction and disappearance of craftsmen's impact on the society in $19^{\text {th }}$ and $20^{\text {th }}$ centuries will be mentioned.
\end{abstract}

Keywords: Akhism, Albania, guild, craftsmen, crafts 
